\title{
Factors Influencing Maize Production in Sikasso Region of Mali
}

https://dx.doi.org/10.4314/jae.v22i3.4

\section{Traore Issa Yassoungo}

Department of Agricultural Extension and Rural Development

University of Ibadan, Ibadan, Nigeria

Email: issayassou@gmail.com

Phone Number: +22375019313

\section{Aminu Oluwafunmilayo Olarewaju}

Department of Agricultural Extension and Rural Development

University of Ibadan, Ibadan, Nigeria

Email: funmiaminu83@gmail.com

Phone Number: +2348060990906

\section{Adekoya Adegbenga Emmanuel}

Department of Agricultural Extension and Rural Development

University of Ibadan, Ibadan, Nigeria

Email: vichenfe12@gmail.com

Phone Number: +234 8023250455/

\section{Abstract}

This study examined the contribution of subsidized inputs to farmers' level of maize production in Sikasso region of Mali. A multistage sampling procedure was used to select 200 beneficiaries of input subsidy for this study. Structured questionnaires were used to collect data which were analysed using descriptive and inferential statistics such as Chi-square, Pearson Product Moment Correction (PPMC), ANOVA and regression at 0.05 significant level. Results reveal beneficiaries' mean age to be 48.50 years. Almost all (99.0\%) beneficiaries were males and married, while $63.5 \%$ had informal education. Mean farm size and mean seasonal income were 3.18 ha and 259,250 Fcfa (\$432) respectively. Subsidized inputs that were mostly used and accessed by beneficiaries were UREA and NPK fertilizers, while Diammonium phosphate, organic fertilizer and hybrid seeds were least accessed and used. Inadequate financial capability to purchase inputs despite being subsidized and insufficiency of inputs were the major constraints faced by beneficiaries. Farm size ( $r=0.57$, $p \leq 0.01)$ and income $(r=0.271, p \geq 0.01)$ were significantly related to respondents' production level. Significant difference exists in the level of maize production among beneficiaries' groups ( $f=8.646, p<? ? 0.01)$. The study concludes that farm size and farmers' income contributed more to farmers' level of maize production. This study recommends that credit should be made available to maize farmers by government, NGOs or other financial institutions with little or no collateral. Also, hybrid seeds that could be preserved till the next planting season should be developed so that farmers' utilisation of hybrid seeds will be encouraged.

Keywords: Farm size, income, maize production, farmers 
Creative commons User License: CC BY-NC-ND

Abstracted by: EBSCOhost, Electronic Journals Service (EJS), Google Scholar, Journal Seek, Scientific Commons,

Food and Agricultural Organization (FAO), CABI and Scopus
Journal of Agricultural Extension

Vol. 22 (3) October, 2018

ISSN(e): 24086851; ISSN(Print); 1119944X

http://journal.aesonnigeria.org

http://www.aiol.info/index.phpliae

Email: editorinchief@aesonnigeria.org

\section{Introduction}

Maize (Zea mays) is one of the most important cereals in Mali. Since its introduction some centuries ago, maize has been the most dominant cereal crop in Southern Mali, precisely Sikasso region. After cotton, maize is a high significant component of the farming system due to its fast growing pattern. Today, maize utilisation goes beyond human consumption. It is highly used for livestock feed production especially by poultry farmers. This had led to increase in the demand for maize in the market. In 2008, as most countries, Mali has known grain crises due to economic crises in the world (Daniela and Auguste, 2009) which affected the agricultural sector in Mali through increasing fertilizer prices on the market. However, the level of maize production reached 2,092,033 tonnes in 2016 (26.0\%) against 1,744,026 tonnes (20.0\%) in 2015 (Ministère de l'Agriculture de l'élevage et de la Pêche, 2016). However, International Fertilizer Development Center - IFDC (2015) asserted that in spite of the increase in quantities of maize produced, it has not been able to meet the demand of consumers. Hence, the need to devise ways such as introduction of subsidized inputs so as to increase farmers' production level. Each time that direct subsidies have been used to promote the use of seed and fertilizer, the results have almost always been disappointing (World Bank, 2008).

The Mali subsidy programme is essentially justified by the problems of productivity and production which arise in agro-ecological zones. These problems are commonly associated with factors such as lack of improved seed, poor quality and unavailability of fertilizer and low use of fertilizers. Usually those who grow cotton and rice benefit the major part of subsidised fertilizers because they are better organised. However, the subsidy programme was also extended to maize producers who also form a very large proportion of the farming population in Mali. It is therefore expected that this programme will positively impact on production of target crops among beneficiaries (IFDC, 2015). According to FAO (2012), a number of assessment studies have been carried out to ascertain the anticipated impacts of input subsidy programme, but have only focused on rice and cotton. Hence, this study examined factors influencing maize production in Sikasso Region of Mali.

\section{Objectives of the Study}

The objectives of the study were to:

1. determine respondents' access to subsidized inputs;

2. examine respondents' utilisation of subsidized inputs;

3. ascertain constraints faced by respondents in accessing subsidized inputs; and

4. assess respondents' level of maize production.

\section{Methodology}

The study was conducted in Sikasso region of Mali which is the second largest city in Mali with an area of $71790 \mathrm{~km}^{2}$. The region is situated in Southeast of Bamako in Mali, North of Ivory Coast and West of Burkina Faso. Sikasso is also a crossroads between the littoral countries (Togo, Benin, Ghana, and Ivory Coast) and non-coastal Mali and Burkina Faso. The population of this study consisted of all maize farmers who are beneficiaries of input subsidy in Sikasso region. Multi-stage sampling procedure was used to select respondents for this study. At the first stage, two circles 
Creative commons User License: CC BY-NC-ND

Abstracted by: EBSCOhost, Electronic Journals Service (EJS), Google Scholar, Journal Seek, Scientific Commons,

Food and Agricultural Organization (FAO), CABI and Scopus
Journal of Agricultural Extension

Vol. 22 (3) October, 2018

ISSN(e): 24086851; ISSN(Print); 1119944X

http://journal.aesonnigeria.org

http://www.ajol.info/index.php/iae

Email: editorinchief@aesonnigeria.org

- Kadiolo and Koutiala were randomly selected from the seven circles in Sikasso region. Kadiolo and koutiala had 9 and 36 communes respectively. At the second stage, $10 \%$ of communes were randomly selected to give 1 and 4 communes from Kadiolo and Koutiala respectively. These communes were Zegoua, Sincina, N'golonianass, kolonigue and KaragouanaMalle with 9, 7, 10, 8 and 5 villages respectively. At the third stage, $25 \%$ of the villages were randomly sampled to give a total of 10 villages. The number of beneficiaries of subsidized inputs in the selected villages was 1,995 . At the fourth stage, $10 \%$ of the beneficiaries were randomly selected to give 200 respondents sampled for this study. The list of beneficiaries was gotten from institutions (CompagnieMalienne pour le Developpement de Textile CMDT - Cotton company in Mali and Direction Regional de l'Agriculture - DRA Regional Department of Agriculture in Mali) responsible for subsidized inputs distribution in the villages. Interview schedule was used to elicit data from respondents. Data collected were presented using descriptive statistics such as frequency, percentage, mean and weighted mean while inferential statistics such as Chi-square, Pearson Product Moment Correlation, ANOVA and regression were used to test hypotheses of the study.

Beneficiaries' accessibility to subsidized inputs was measured using a 3-point scale of always, occasional and never with scores of 2,1 and 0 assigned respectively. Utilisation of subsidized inputs was measured using a 3-point scale of totally utilised, occasionally utilised and not utilised with scores of 2,1 and 0 assigned respectively. Constraints faced by beneficiaries in accessing subsidized inputs were determined by using a 3-point scale of major, mild and not a constraint with scores of 2, 1 and 0 assigned respectively. In addition to the use of percentages, weighted mean value for each item on accessibility, utilisation and constraints were computed and used to rank the items for the three aforementioned variables. Level of maize production was determined by asking beneficiaries to indicate quantity of maize produced in year 2016 in tonnes. Mean of tonnes of maize produced was computed and used to categorized beneficiaries as either having high level of production for those with quantity of maize produced equal to and above the mean or low level of production for those with quantity of maize produced below the mean.

\section{Results and Discussion}

\section{Socioeconomic Characteristics}

Table 1 reveals that $40.5 \%$ and $30.5 \%$ of respondents were within the age groups of 35-47 and 48-60 years respectively. The mean age was 48.59 years, implying that beneficiaries are more of adults compared to youths. Respondents' mean age was closed to that reported by Oladejo and Adetunji (2012) who conducted a study among maize farmers in Oyo State, Nigeria and found their mean age to be 45.8 years. However, Ajah and Nmadu (2012) conducted a study on small scale farmers' access to maize input in Abuja, Nigeria and found average age of farmers to be 39.0 years. Almost all $(99.0 \%)$ of the respondents were males, implying that men were the main beneficiaries of subsidized inputs and are predominantly involved in maize production in the study area. This result corroborates the findings of Garcia, Nyberg and Shayma (2006) that the past agricultural development interventions tend to focus on male 
maize producers at the expense of female maize producers because men form the largest percentage of the workforce in agricultural production in the rural area of Mali.

Most (99.0\%) of the respondents were married and this could be due to the fact that people got married early in rural area of Mali and farming system is family based. All the family members cultivate the same land collectively and the farm is usually registered in the name of family chief. Hence, gender sensitivity is neglected in the study area by subsidy programme. The majority of the beneficiaries (63.5\%) had no formal education, $24.0 \%$ had not received any form of education while $12.5 \%$ had formal education. The low educational level of respondents could have negative effect on their receptivity of innovations as previous studies have shown that producers who had high level of education are likely to adopt new technologies earlier and use inputs that make them more productive compared to those with low educational level (Afari, 2001). According to Iwaola (2014), education is an important factor in accessing subsidized inputs, agricultural information and in understanding the need for involvement in agricultural intervention programme such as input subsidy programme.

Table1 also shows that $54.5 \%$ and $30.5 \%$ of the respondents cultivated between $1.0-$ 2.0 and 2.1-5.0 hectares (ha) respectively with mean farm size was 3.18 ha. All $(100.0 \%)$ of the respondents belonged to social groups implying that they were organized system of producers. It is noteworthy that inputs are delivered to the various cooperatives and then shared among producers since they benefited as a group and not as individual. This implies that membership in social groups provided an opportunity for respondents to access subsidized inputs. This finding is in line with Ajah et al (2015) that farmers who belong to one form of social group or other tend to have access to farm inputs. It was found that $73.5 \%$ of the respondents earned a seasonal income between 3,000 - 303,000 Fcfa $(\$ 5$ - \$505) with a mean income of 259,250 Fcfa (\$432). Furthermore, Table 1 reveals that all respondents got subsidized inputs from government institutions which are CMDT and DRA. Respondents who sourced subsidized inputs from CMDT and DRA only were 50.0\% and $35.0 \%$ respectively, while $15.0 \%$ sourced inputs from both institutions. 
Creative commons User License: CC BY-NC-ND

Abstracted by: EBSCOhost, Electronic Journals Service (EJS),

Google Scholar, Journal Seek, Scientific Commons,

Food and Agricultural Organization (FAO), CABI and Scopus
Journal of Agricultural Extension

Vol. 22 (3) October, 2018

ISSN(e): 24086851; ISSN(Print); 1119944X

http://journal.aesonnigeria.org

http://www.ajol.info/index.php/iae

Email: editorinchief@aesonnigeria.org

Table1: Socioeconomic characteristics of respondents

\begin{tabular}{|c|c|c|c|}
\hline Variables & Percentage $(n=200)$ & Mean & Std.deviation \\
\hline \multicolumn{4}{|l|}{ Age in years } \\
\hline $21-34$ & 11.5 & & \\
\hline $35-47$ & 40.5 & & \\
\hline $48-60$ & 30.5 & 48.59 & 12.63 \\
\hline $61-73$ & 14.5 & & \\
\hline$>73$ & 3.0 & & \\
\hline \multicolumn{4}{|l|}{ Sex } \\
\hline Male & 99.0 & & \\
\hline \multicolumn{4}{|l|}{ Marital status } \\
\hline Single & 1.0 & & \\
\hline Married & 99.0 & & \\
\hline \multicolumn{4}{|l|}{ Level of education } \\
\hline No education & 24.0 & & \\
\hline informal education & 63.5 & & \\
\hline Primary education & 12.0 & & \\
\hline Secondary education & - & & \\
\hline Tertiary education & 0.5 & & \\
\hline \multicolumn{4}{|l|}{ Farm size (ha) } \\
\hline $1.0-2.0$ & 54.5 & 3.18 & 2.72 \\
\hline $2.0-5.0$ & 30.5 & & \\
\hline$>5.0$ & 15.0 & & \\
\hline \multicolumn{4}{|l|}{$\begin{array}{l}\text { Membership of social } \\
\text { groups }\end{array}$} \\
\hline Yes & 100.0 & & \\
\hline \multicolumn{4}{|c|}{ Seasonal Income (Fcfa) } \\
\hline $3,000-303,000$ & 73.5 & 259250.00 & 286592.90 \\
\hline $303,001-603,001$ & 19.0 & & \\
\hline $603,002-903,002$ & 4.0 & & \\
\hline$>903,003$ & 3.5 & & \\
\hline \multicolumn{4}{|l|}{ Sources of inputs } \\
\hline \multirow{2}{*}{\multicolumn{4}{|c|}{ Name of institution }} \\
\hline & & & \\
\hline CMDT & 50.0 & & \\
\hline DRA & 35.0 & & \\
\hline $\mathrm{DRA}+\mathrm{CMDT}$ & 15.0 & & \\
\hline
\end{tabular}

Source: Field Survey, 2017

\section{Beneficiaries' Access to Subsidized Inputs}

Table 2 shows that subsidized inputs accessed by farmers include urea $(\bar{x}=1.84)$, NPK $(\bar{x}=1.84)$, Diammonium phosphate (DAP) $(\bar{x}=0.6)$, organic fertilizer $(\bar{x}=0.27)$

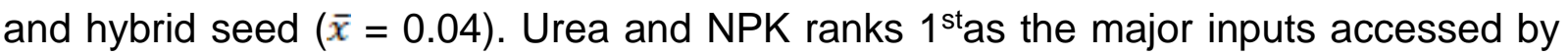
respondents while Organic fertilizer, DAP and hybrid seed ranks $2^{\text {nd }}$, $3^{\text {rd }}$ and $4^{\text {th }}$ respectively and these were least accessed by respondents. The low accessibility of hybrid seed by respondents could be attributed to low level of availability and high cost. IFDC (2015) reported that although the subsidy programme concerns all targeted crop producers, not all producers can easily access subsidized inputs. Corroborating this, maize farmers stated thus during the course of this survey that:

"though these inputs were subsidized, but failure to pay for those initially collected on credit makes it difficult for me to access another input".

"I have made several attempts to obtain hybrid seed, each time I go there I will be told that they are not available". 
"It is difficult to keep hybrid seed for cultivation in next farming season, as a result, I get discourage to cultivate hybrid seeds because you cannot keep them like the local seeds for next planting seasons".

Table 2: Beneficiaries' access to subsidized inputs

\begin{tabular}{lcc}
\hline Inputs & Weighted mean & Rank \\
\hline UREA & 1.84 & $1^{\text {st }}$ \\
NPK & 1.84 & $1^{\text {st }}$ \\
Organic fertilizer & 0.27 & $2^{\text {nd }}$ \\
DAP & 0.06 & $3^{\text {rd }}$ \\
Hybrid seed & 0.04 & $4^{\text {th }}$ \\
\hline
\end{tabular}

Source: Field Survey, 2017

\section{Beneficiaries' Utilisation of Subsidized Inputs}

Table 3 reveals that urea $(\bar{x}=1.95)$ and NPK $(\bar{x}=1.99)$ were used by most respondents. This could be attributed to the fact that most respondents had access to the aforementioned inputs. The majority of the respondents did not use DAP $(\bar{x}=$ $0.05)$, organic fertilizer $(\bar{x}=0.15)$ and hybrid seed $(\bar{x}=0.04)$. This could be attributed to the low level of accessibility of DAP, organic fertilizer and hybrid seeds. Findings from this study agrees with Sonwa et al. (2008) who identified inadequate access and high cost as major constraints to utilizing inputs in rural areas.

Table 3:Beneficiaries'utilisation of subsidized inputs

\begin{tabular}{lcc}
\hline Inputs & Weighted mean & Rank \\
\hline NPK & 1.99 & $1^{\text {st }}$ \\
UREA & 1.95 & $2^{\text {nd }}$ \\
Organic fertilizer & 0.15 & $3^{\text {rd }}$ \\
DAP & 0.05 & $4^{\text {th }}$ \\
Hybrid seed & 0.04 & $5^{\text {th }}$ \\
\hline
\end{tabular}

Source: Field Survey, 2017

\section{Constraints to Accessing Subsidized Inputs}

Table 4 shows that high cost of inputs $(\bar{x}=0.75)$ ranked $1^{\text {st }}$ among the constraints faced by maize producers in accessing subsidized inputs. This could be attributed to the fact that respondents in the study area are small scale farmers with low income level and as such find it difficult to afford subsidized inputs. Insufficient inputs ( $\bar{x}=$ 0.61 ) and unavailability of inputs $(\bar{x}=0.58)$ also constituted major constraints to accessibility of subsidized inputs among maize producers. When inputs are not sufficient or available, it becomes difficult for producers to access them. Poor information on subsidized input $(\bar{x}=0.13)$ and poor marketing strategy $(\bar{x}=0.13)$ were the least constraints faced by maize farmers. The plausible reason for this could be attributed to respondents' membership in association which facilitates flow of information that could be of benefit to maize production. 
Table 4: Constraints to accessing subsidised inputs

\begin{tabular}{lcc}
\hline Constraints & $\begin{array}{c}\text { Weighted } \\
\text { mean }\end{array}$ & Rank \\
\hline High cost of inputs & 0.75 & $1^{\text {st }}$ \\
Inputs are not sufficient to meet maize producers need & 0.61 & $2^{\text {nd }}$ \\
Inputs not readily available & 0.58 & $3^{\text {rd }}$ \\
Remoteness of maize producers location & 0.38 & $4^{\text {th }}$ \\
Inadequate credit & 0.30 & $5^{\text {th }}$ \\
Input is of poor quality & 0.27 & $6^{\text {th }}$ \\
Inputs not easily accessible & 0.27 & $6^{\text {th }}$ \\
Poor information & 0.13 & $7^{\text {th }}$ \\
Ineffective marketing strategy & 0.13 & $7^{\text {th }}$ \\
\hline
\end{tabular}

Source: Field survey (2017)

\section{Level of Maize Production in Year 2016}

The result in Table 5 reveals that $62.5 \%$ of the respondents had low production level while $37.5 \%$ of them had high production level with a mean production of 61.48 tonnes. It could be deduced that this result is a reflection of the arrays of constraints faced by respondents in the study area.

Table 5:Distribution of beneficiaries based on their level of maize production Level of production Percentages $(n=200) \quad$ Mean Standard deviation in tonnes

\begin{tabular}{llll} 
Low $(<$ mean $)$ & 62.5 & 61.48 & 58.79 \\
High $(\geq$ mean $)$ & 37.5 & & \\
\hline
\end{tabular}

Source: Field survey (2017)

\section{Relationship Between Selected Independent Variables and Maize Production}

However, the Pearson Product Moment Correlation between farm size $(r=0.57$, $p ? ? 0.01)$, income $(r=0.271, p<0.01)$ and maize production was significant but age $(r=$ $0.114, p>0.109$ ) was not significantly related to maize production. This implies that producers' farm size and income significantly affects maize producers' level of production. Thus, producers with high income level can afford subsidized inputs and other resources required for maize production. Also, the significant influence of farm size on production level suggests that the larger the farm size cultivated, the higher the expected output/yield. Hence, increase in maize production is linked to increase in land size cultivated for maize.

Table 6: Relationship between selected independent variables and maize production

\begin{tabular}{lll}
\hline Variables & $\mathrm{X}^{2}$ & r-value \\
\hline Age & & 0.114 \\
Level of education & 4.087 & \\
Farm size & & $0.572^{*}$ \\
Income & & $0.271^{*}$ \\
\hline
\end{tabular}


Creative commons User License: CC BY-NC-ND

Abstracted by: EBSCOhost, Electronic Journals Service (EJS), Google Scholar, Journal Seek, Scientific Commons,

Food and Agricultural Organization (FAO), CABI and Scopus
Journal of Agricultural Extension

Vol. 22 (3) October, 2018

ISSN(e): 24086851; ISSN(Print); 1119944X

http://journal.aesonnigeria.org

http://www.ajol.info/index.php/iae

Email: editorinchief@aesonnigeria.org

\section{Factors Contributing to Beneficiaries' Level of Maize Production}

Independent variables were regressed with the level of maize production to determine their contribution to farmers' level of production. The result in Table 6shows that farmers' farm size $(\beta=0.546, P<0.01)$ and income $(\beta=0.167, P<0.01)$ significantly predicted farmers' level of production with percentage contribution of $54.6 \%$ and $16.7 \%$ respectively. The analysis indicated an $\mathrm{R}$ square value of 0.397 , indicating that the independent variables in the regression model can only explained $39.7 \%$ contribution to the dependent variable. The non-significant variables are not important contributors to farmers' level of maize production in the study area.

Table 7: Factor contributing to beneficiaries' level of maize production

\begin{tabular}{lccc}
\hline & S.E & B & t \\
\hline (Constant) & 240.193 & & \\
Sex & 101.270 & 0.037 & 0.641 \\
Religion & 26.317 & 0.036 & 0.610 \\
Marital Status & 103.658 & 0.052 & 0.883 \\
Education & 16.322 & -0.034 & -0.585 \\
Farm size & 14.281 & 0.546 & $9.168^{\star}$ \\
Income & 12.017 & 0.167 & $2.849^{\star}$ \\
Access & 8.901 & 0.062 & 0.956 \\
Utilisation & 15.436 & 0.062 & 0.948 \\
Constraint & 3.640 & 0.017 & 0.299 \\
\hline R= 0.630; $\mathrm{R}^{2}=0.397 ;$ Adjusted $\mathrm{R}^{2}=0.368 ;$ Std. Error $=140.2902 ;$ \\
p<0.01
\end{tabular}

Source: Field Survey, 2017

\section{Conclusion and Recommendations}

Farm size and income contributed significantly to farmers' level of maize production. The level of farmers' accessibility to and utilization of organic fertilizer, DAP and hybrid seeds was very low. Farmers' major constraint was inadequate capital to purchase inputs despite being subsidized.

Credit should be made available to maize farmers by government, non-governmental organisations and financial institutions with little or no collateral in order to boost their financial capacity. Organic fertilizer, DAP and hybrid seeds should be made available to farmers by institutions responsible for input distribution. Extension agents should encourage maize farmers to increase their farm size with respect to inputs within their reach.

\section{References}

Afari, E. (2001). The Effect of Farmers' Education on Farm Productivity and Income in Ghana: Implication for Food Security. A Ph. D Thesis in the Department of Agricultural Economics and Agribusiness, University of Ghana. 
Creative commons User License: CC BY-NC-ND

Abstracted by: EBSCOhost, Electronic Journals Service (EJS), Google Scholar, Journal Seek, Scientific Commons,

Food and Agricultural Organization (FAO), CABI and Scopus
Journal of Agricultural Extension

Vol. 22 (3) October, 2018

ISSN(e): 24086851; ISSN(Print); 1119944X

http://journal.aesonnigeria.org

http://www.ajol.info/index.php/iae

Email: editorinchief@aesonnigeria.org

Ajah J. and Nmadu J. N. (2012). Small scale maize farmers access to farm inputs in Abuja, Nigeria. Kasetsart Journal of Social Sciences Vol. 33:333 - 341

Ajah, L. O., Chigbu, C. O., Ozumba, B. C., Oguanuo, T. C., and Ezeonu, P. O. (2015). Is there any association between hormonal contraceptives and cervical neoplasia in a poor Nigerian setting? OncoTargets and therapy, 8, 1887.

Daniela G. and Auguste T. K. (2009). The Global Financial and Economic Crisis: Transmission Channels and Policy Response in the Arab world. MENA Knowledge and Learning Quick Notes Series; No. 1. World Bank, Washington, DC. (C) World Bank. https://openknowledge.worldbank.org/handle/10986/10999

Food and Agricultural Organisation - FAO (2012).Smallholders and Family Farmers. Retrieved

fromhttp://www.fao.org/fileadmin/templates/nr/sustainability_pathways/docs/Factsheet

Garcia, Nyberg and Shayma, 2006; MuGede, (2013).Agriculture, Trade Negotiations and Gender.Rome: Food and Agriculture Organisation. Retrieved from http://www.fao.org/docrep/009/a0493e03.htm.

International Fertilizer Development Center - IFDC (2015). The African Fertilizer and Agribusiness Partnership: Mali Fertilizer Assessment", Muscle Shoals, Alabama, U. S. A. 2001. pp: 6-13 https://ifdcorg.files.wordpress.com/2016/05/mali-fertilizerassessment.pdf

Iwaola, O. S. (2014). Economic impact, viability and sustainability of Fadama II small scale community owned infrastructure in Ondo State, Nigeria. American Journal of Research communication, Vol. 2(5), 60-70.

Ministère de l'Agriculture de l'élevage et de la Pêche, (2016). Plan de Campagne Agricole 2015-2016. pp. 1-137

Oladejo, J. A. and Adetunji, M. O. (2012). Economic analysis of maize (zea mays I.) productionin Oyo state of Nigeria.Agricultural Science Research Journals Vol. 2(2): 77-83

Sonwa, D. J., Coulibaly, O., Weise, S. F., Adesina, A. A., and Janssens, M. J. (2008). Management of cocoa: constraints during acquisition and application of pesticides in the humid forest zones of southern Cameroon. Crop Protection, 27(8), 1159-1164.

World Bank, (2008). World development report. Retrieved from:

http://documents.worldbank.org/curated/en/359971468137706090/New-approaches-toinput-subsidies 